\title{
Gas Chromatography-Mass Spectrometry Study of the Essential Oils of Schinus longifolia (Lindl.) Speg., Schinus fasciculata (Griseb.) I. M. Johnst., and Schinus areira $\mathbf{L}$.
}

\author{
Ana P. Murray*a,b, María A. Frontera ${ }^{a}$, María A. Tomas ${ }^{a}$, and María C. Mulet \\ a Instituto de Investigaciones en Química Orgánica, Departamento de Química, \\ Universidad Nacional del Sur, Avenida Alem 1253, (8000) Bahía Blanca, Argentina. \\ Fax: 542914595187. E-mail: apmurray@criba.edu.ar \\ b Consejo Nacional de Investigaciones Científicas y Tecnológicas, Argentina \\ * Author for correspondence and reprint requests \\ Z. Naturforsch. 60c, 25-29 (2005); received August 6/September 10, 2004
}

The essential oil composition from the aerial parts of three Anacardiaceae growing in Bahía Blanca, Argentina was studied by gas chromatography and gas chromatography-mass spectrometry. The essential oils of $S$. longifolia and S. fasciculata have been studied for the first time. The major constituents were $\alpha$-pinene $(46.5 \%), \beta$-pinene $(15.1 \%)$ and $\alpha$-phellandrene $(10.1 \%)$ for S. longifolia and limonene $(10.9 \%), \beta$-phellandrene $(6.16 \%)$ and $\alpha$-phellandrene $(5.6 \%)$ for $S$. fasciculata. The major components of the essential oil of $S$. areira were limonene $(28.6 \%), \alpha$-phellandrene $(10.1 \%)$, sabinene $(9.2 \%)$ and camphene $(9.2 \%)$ differing from the literature data. The essential oils from $S$. areira and $S$. longifolia exhibited a high biotoxicity in a brine shrimp assay with Artemia persimilis.

Key words: Schinus, Essential Oil, Biotoxicity

\section{Introduction}

The genus Schinus (family Anacardiaceae) comprises twenty-two species, six of them are endemic in Argentina. In the southwest of Buenos Aires province, particularly in the region of Bahía Blanca, three species of the genus Schinus can be found, Schinus longifolia (Lindl.) Speg., Schinus fasciculata (Griseb.) I. M. Johnst., and Schinus areira L. (Zuloaga and Morrone, 1999; Cabrera, 1965).

Schinus fasciculata is a thorny shrub known as "Molle Pispito". It is used in the folk medicine of the northwest of Argentina as an antitussive and for treatment of dysentery (Scarpa, 2004). This species is endemic in Argentina and can be found in Northern and Central provinces of our country and also in Paraguay and Bolivia. Schinus longifolia is a medium-size tree $(5 \mathrm{~m})$ that is frequently found in the area of Buenos Aires province, Argentina, and also in Brazil and Uruguay. Its leaves are used in the treatment of colds, as expectorant and laxative, the resin that exudates is used as emollient. No previous record on phytochemical studies of these two species has been found in the literature.

Schinus areira, previously named as Schinus molle, is an evergreen tree up to $10 \mathrm{~m}$ in height, locally known by its common names "Aguarybay" or "Gualeguay". Widely distributed in America it is well known by its several uses in the folk medicine, so far it is called "Balsamo sanalotodo" (cure-all balsam). Leaves, fruits, stems and bark, dried or fresh, are used to prepare infusions, ointments, cataplasms, beverages, collyrium, etc. which are used as purgative, diuretic, parasiticide, insecticide, vulnerary, topic disinfectant and for the treatment of rheumatism, stomach upset, menstrual disorders, bronchitis and conjunctivitis (Gupta, 1995). Besides, fruits are used as a substitute of "black pepper" and in the preparation of alcoholic drinks. The essential oil of $S$. areira has shown significant antibacterial and antifungal activity (Gundidza, 1993; Dikshit et al., 1986). Limonene and $\alpha$-pinene, components of the essential oil of $S$. areira, and the oil itself have been studied as allelopathic agents showing strong inhibitory activity of the root growth of Zea mays seedlings (Scrivanti et al., 2003).

In the present work we are reporting for the first time the chemical composition of the essential oils of S. longifolia and S. fasciculata. Besides, the chemical composition of the essential oil of $S$. areira is analyzed and compared with previously reported data for $S$. areira from different locations 
in Argentina. The biotoxicity of these oils has been evaluated through the brine shrimp assay observing the percentage of mortality of Artemia nauplii at different oil concentrations.

\section{Materials and Methods}

\section{General}

Gas chromatography-mass spectrometry analyses were performed with a Hewlett-Packard 6890 chromatograph connected to a Hewlett-Packard 5972 A mass spectrometer equipped with a capillary column (HP-5, $30 \mathrm{~m}$ x $0.25 \mathrm{~mm}, 0.25 \mathrm{~mm}$ film thickness). The carrier gas was helium with a flow of $1 \mathrm{ml} / \mathrm{min}$. The GC oven temperature was held at $60^{\circ} \mathrm{C}$ for $1 \mathrm{~min}$, programmed at $5^{\circ} \mathrm{C} / \mathrm{min}$ to $250{ }^{\circ} \mathrm{C}$, then held at this temperature for $15 \mathrm{~min}$. Mass spectra were recorded at $70 \mathrm{eV}$. Mass range was from $\mathrm{m} / \mathrm{z} 35$ to $350 \mathrm{amu}$. The temperature of the injection block was $250{ }^{\circ} \mathrm{C}$.

GC analyses were performed on a Shimadzu G14B chromatograph with a flame ionization detector on a DB-1 column $(50 \mathrm{~m} \times 0.25 \mathrm{~mm}$, $0.25 \mu \mathrm{m}$ film thickness) and a Carbowax 20M column ( $50 \mathrm{~m} \times 0.25 \mathrm{~mm}, 0.25 \mu \mathrm{m}$ film thickness) with the same analytical conditions used for the GC-MS analyses.

\section{Plant material}

Aerial parts of $S$. longifolia and $S$. areira were collected in August 2003 at Bahía Blanca city, Buenos Aires province, Argentina. Aerial parts of S. fasciculata were collected in May 2004 at Puerto Cuatreros, near Bahía Blanca. The taxonomy of this material was determined by Lic. M. G. Murray. Voucher specimens are kept in the "Herbario del Departamento de Biología, Bioquímica y Farmacia - Universidad Nacional del Sur (BBB)" under the numbers MGM121 (S. areira), MGM401 and MGM402 (S. fasciculata) and MGM400 (S. longifolia).

\section{Isolation of the essential oils}

The samples of S. longifolia (153 g), S. fasciculata $(171 \mathrm{~g})$ and $S$. areira $(160 \mathrm{~g})$ consisting of fresh picked aerial parts (leaves, fruits and stems) were subjected to hydrodistillation using a Clevenger type apparatus for $3 \mathrm{~h}$. The oils were dried over anhydrous sodium sulfate and stored at $4{ }^{\circ} \mathrm{C}$ under $\mathrm{N}_{2}$. Essential oils yields were $0.23 \%, 0.26 \%$ and $2.22 \%$ for S. longifolia, S. fasciculata and S. areira, respectively, based on fresh weight of sample.

\section{Identification of the compounds}

The compounds were identified by gas chromatography by comparison of their retention indices (Kovats Indices) with retention times of known compounds and also by comparison of their mass spectra with those stored in the MS databases (NBS75K.L MS DATA). Relative percentage amounts were obtained directly from GC peak areas. Results are summarized in Table I.

\section{Brine shrimp bioassay}

Each of the essential oils was tested at 1000, 100 and $10 \mu \mathrm{g}$ of oil per $\mathrm{ml}$. The concentrations were obtained by transferring the corresponding volume from the stock dichloromethane solutions to different wells, air drying overnight and redissolving in $3 \mathrm{ml}$ of artificial sea water ( $35 \mathrm{~g}$ of sea salts "Marsal" per litre of deionized water). Brine shrimp eggs of the Argentine species Artemia persimilis obtained locally (Acuario Indico, Buenos Aires, Argentina) were hatched in artificial sea water at room temperature under continuous lighting. After an incubation time of $48 \mathrm{~h}, 100 \mu \mathrm{l}$ of this solution containing 10-20 organisms were pipetted into each well and then incubated for $48 \mathrm{~h}$ under direct light at $24-26{ }^{\circ} \mathrm{C}$. Then, each well was examined and the number of dead (i.e. nonmotile) nauplii was counted. Finally, $100 \mu \mathrm{l}$ of methanol were added to each well and after 30 min the total number of shrimp in each well was counted. Triplicate assays were run for each concentration and control and the average value of the three assays was recorded. The controls were performed with the same amount of $\mathrm{CH}_{2} \mathrm{Cl}_{2}$ used for the dilutions of the samples, following the same procedure. Results are reported as percentage of mortality in Table II where $\mathrm{M}=$ (percentage of survival in the control - percentage of survival in the sample).

\section{Results and Discussion}

The hydrodistillation of the aerial parts of S. longifolia gave a colorless oil with a yield of $0.23 \%$ based on fresh weight. Thirteen compounds $(98.19 \%)$, almost exclusively monoterpenes $(93.35 \%)$, were identified and the major constituents were $\alpha$-pinene $(46.51 \%), \beta$-pinene $(15.13 \%), \quad \alpha$-phellandrene $(10.11 \%)$, limonene (7.70\%) and $\beta$-myrcene (6.98\%). All the identified compounds, their percentages and retention times are listed in Table I. 
Table I. Constituents of essential oils from aerial parts of Schinus longifolia, Schinus fasciculata and Schinus areira.

\begin{tabular}{|c|c|c|c|c|c|}
\hline Components $^{\mathrm{a}}$ & $\begin{array}{c}\mathrm{RT} \\
{[\mathrm{min}]}\end{array}$ & S. longifolia & $\begin{array}{l}\text { Percentage } \\
\text { S. fasciculata }\end{array}$ & S. areira & $\begin{array}{l}\text { Method of } \\
\text { identification }^{b}\end{array}$ \\
\hline Tricyclene & 6.25 & 1.50 & - & 2.20 & GC-MS, RI \\
\hline Hexanal & 6.47 & - & 4.20 & - & GC-MS, RI \\
\hline Octane & 6.51 & - & 1.10 & - & GC-MS, RI \\
\hline 2-Hexenal $(E)$ & 6.85 & - & 1.21 & - & GC-MS, RI \\
\hline 3-Hexen-1-ol $(Z)$ & 6.90 & - & 5.12 & - & GC-MS, RI \\
\hline 1-Hexanol & 7.53 & - & 8.03 & - & GC-MS, RI, S \\
\hline Nonane & 7.89 & - & 7.60 & - & GC-MS, RI \\
\hline$\alpha$-Pinene & 8.52 & 46.51 & 3.84 & 6.51 & GC-MS, RI, S \\
\hline Camphene & 9.12 & 5.26 & - & 9.16 & GC-MS, RI \\
\hline Sabinene & 9.87 & - & - & 9.20 & GC-MS, RI \\
\hline$\beta$-Pinene & 10.12 & 15.13 & 4.20 & 7.23 & GC-MS, RI, S \\
\hline$\beta$-Myrcene & 10.71 & 6.98 & - & 5.98 & GC-MS, RI \\
\hline 2-Carene & 10.89 & - & 3.19 & - & GC-MS, RI \\
\hline$\alpha$-Phellandrene & 11.08 & 10.11 & 5.60 & 10.11 & GC-MS, RI \\
\hline Limonene & 12.28 & 7.70 & 10.90 & 28.61 & GC-MS, RI, S \\
\hline$\beta$-Phellandrene & 13.10 & - & 6.16 & - & GC-MS, RI \\
\hline 3-Carene & 13.90 & 0.16 & 1.78 & 0.16 & GC-MS, RI \\
\hline 1-Octanol & 14.13 & - & 0.46 & - & GC-MS, RI, S \\
\hline Nonanal & 14.47 & 1.08 & 1.42 & $\operatorname{tr}^{\mathrm{c}}$ & GC-MS, RI \\
\hline 2,6-Nonadienal $(E, Z)$ & 15.87 & - & 1.50 & - & GC-MS, RI \\
\hline Decanal & 17.15 & - & 1.45 & - & GC-MS, RI \\
\hline 1-Decanol & 18.64 & - & 1.80 & - & GC-MS, RI \\
\hline 2-Undecanone & 20.10 & - & 1.17 & - & GC-MS, RI \\
\hline Exo-2-hydroxycineole acetate & 21.46 & - & - & 0.20 & GC-MS, RI \\
\hline$\alpha$-Cubebene & 21.70 & - & - & 6.61 & GC-MS, RI \\
\hline$\alpha$-Copaene & 22.47 & 0.79 & - & 0.79 & GC-MS, RI \\
\hline$\beta$-Elemene & 22.67 & - & - & 0.24 & GC-MS, RI \\
\hline 1-Decene & 22.72 & - & 12.34 & - & GC-MS, RI \\
\hline Caryophyllene & 23.66 & 0.34 & - & 1.44 & GC-MS, RI \\
\hline Humulene & 24.49 & 0.08 & - & 0.87 & GC-MS, RI \\
\hline Heptyl hexanoate & 24.94 & - & 0.78 & - & GC-MS, RI \\
\hline Butyl hexanoate & 26.85 & - & 2.48 & - & GC-MS, RI \\
\hline Germacrene B & 27.78 & 2.55 & - & 4.05 & GC-MS, RI \\
\hline Globulol & 28.24 & - & - & 0.81 & GC-MS, RI \\
\hline 1-Dodecanol & 29.98 & - & 9.21 & - & GC-MS, RI \\
\hline Spathulenol & 32.86 & - & - & 0.42 & GC-MS, RI \\
\hline$\alpha$-Santalol & 34.16 & - & - & 0.17 & GC-MS, RI \\
\hline Kauren-18-ol acetate & 34.82 & - & - & 0.15 & GC-MS, RI \\
\hline
\end{tabular}

a Components are listed in order of elution on HP-5 (30 m) column.

b GC-MS: gas chromatography-mass spectrometry; RI: Kovats Index; S: standard.

c tr: traces $<0.05 \%$.

The analysis of the essential oil of $S$. fasciculata allowed us to identify twenty-three compounds (95.54\%), among them limonene (10.90\%), $\beta$-phellandrene $(6.16 \%)$ and $\alpha$-phellandrene $(5.60 \%)$ were the major terpenes (Table I). It is to note that a high percentage of compounds like alcohols $(24.62 \%)$, aldehydes $(9.78 \%)$, esters $(3.26 \%)$ and ketones $(1.17 \%)$ was present in this hydrodistillated oil whereas a low content of monoterpenes $(35.67 \%)$ and none sesquiterpenes were detected. In this case the essential oil was obtained with a yield of $0.26 \%$ based on fresh weight.
In the essential oil of $S$. areira (yield 2.22\%) twenty-one compounds were identified $(94.3 \%)$ (Table I). The major ones were limonene $(28.61 \%), \quad \alpha$-phellandrene $(10.11 \%)$, sabinene $(9.20 \%)$ and camphene $(9.16 \%)$. These results differ from those reported for S. areira specimens collected in Córdoba province, middle region of Argentina, where the major component was $\alpha$-pinene (85\%) (Scrivanti et al., 2003). For specimens collected in Mendoza province, West of Argentina, the composition was similar but with a higher percentage of limonene (45.95\%) and a-phellandrene 
(25.44\%) (Wannaz et al., 2003). Finally, our results

Table II. Toxicity of the essential oils of Schinus longifolia, Schinus fasciculata and Schinus areira against Artemia persimilis.

\begin{tabular}{lccc}
\cline { 2 - 4 } & \multicolumn{3}{c}{$\mathrm{M}(\%)^{\mathrm{a}}$} \\
\hline Oil concentration $[\mu \mathrm{g} / \mathrm{ml}]$ & 1000 & 100 & 10 \\
\hline S. longifolia & 94.4 & 63.0 & 12.9 \\
S. fasciculata & 0 & 0 & 0 \\
S. areira & 100.0 & 100.0 & 10.2 \\
\hline
\end{tabular}

${ }^{a}$ Percentage of mortality after $48 \mathrm{~h}$ of exposure.

also differ from those obtained in a study with several samples collected in Jujuy province, northwest of Argentina, where the main component of the essential oil of $S$. areira was $\beta$-phellandrene which was absent in our sample (Viturro et al., 2003). Thus, for plants of $S$. areira growing in different regions of Argentina, a marked variability in the chemical composition of the essential oil can be observed. This variability may be attributed to different climatic and soil growing conditions.

The shrimp bioassay is based on the ability to kill laboratory-cultured Artemia nauplii brine shrimp. This assay is considered a useful tool for preliminary assessment of toxicity (Solis et al., 1993; McLaughlin et al., 1991; Sorgeloos et al., 1978). A good relationship has been found with the brine shrimp assay to detect antitumoral compounds in terrestrial plant extracts (Solis et al., 1993; Meyer et al., 1982; Mackeen et al., 2000), and potentially cytotoxic metabolites in marine natural products (Carballo et al., 2002). This encouraged us to test the essential oil of $S$. longifolia, $S$. fasciculata and $S$. areira with the brine shrimp assay. The results of the bioassay are summarized in Table II. After $48 \mathrm{~h}$ of exposure a mortality of $100 \%$ was observed for $S$. areira oil at concentrations of 1000 and $100 \mu \mathrm{g} / \mathrm{ml}$. The oil of $S$. longifolia showed $94.4 \%$ mortality for an oil concentration of $1000 \mu \mathrm{g} / \mathrm{ml}$ and $63.0 \%$ mortality for $100 \mu \mathrm{g} / \mathrm{ml}$. Both gave similar results $(\sim 10 \%)$ for the more diluted samples $(10 \mu \mathrm{g} / \mathrm{ml})$. On the other hand, the oil of S. fasciculata showed no activity $(100 \%$ of survival) in the brine shrimp assay. These results could be explained considering the differences in the chemical composition of the essential oils of these Schinus species which are shown in Table III. While the essential oil of $S$. fasciculata gave a low percentage of monoterpenes $(35.67 \%)$ and no sesquiterpenes could be detected, S. longifolia and $S$. areira gave higher contents of monoterpenes, $93.35 \%$ and $79.16 \%$, respectively, and sesquiterpenes, $3.76 \%$ and $15.40 \%$, respectively. The results of this bioassay suggest that the essential oils of $S$. areira and S. longifolia are good candidates for further evaluation of cytotoxicity and antitumoral activity.

\section{Acknowledgements}

The authors are grateful to Lic. M. G. Murray for the taxonomic identification of the plant material and the collection of $S$. fasciculata. This work was financially supported by Universidad Nacional del Sur and Fundación Antorchas. A. P. M. thanks Dra. Alicia Chopa.

\begin{tabular}{lccc}
\hline Grouped components & $\begin{array}{c}\text { S. longifolia } \\
(\%)\end{array}$ & $\begin{array}{c}\text { S. fasciculata } \\
(\%)\end{array}$ & $\begin{array}{c}\text { S. areira } \\
(\%)\end{array}$ \\
\hline Monoterpene hydrocarbons & 93.35 & 35.67 & 79.16 \\
Sesquiterpene hydrocarbons & 3.76 & - & 15.40 \\
Esters & - & 3.26 & 0.35 \\
Aldehydes & 1.08 & 9.78 & $\mathrm{tr}^{\mathrm{a}}$ \\
Ketones & - & 1.17 & - \\
Alcohols & - & 24.62 & - \\
Aliphatic and olefinic hydrocarbons & - & 21.04 & - \\
Total identified & 98.19 & 95.54 & 94.93 \\
\hline
\end{tabular}

Table III. Percentage composition of grouped components of essential oils of Schinus longifolia, Schinus fasciculata and

Schinus areira.

Aliphatic and olefinic hydrocarbons

98.19

21.04
95.54

a $\operatorname{tr}$ : traces $<0.05 \%$ 
Cabrera A. (1965), Flora de la Provincia de Buenos Aires. Parte IV. Ed. Col. Cient. INTA, Buenos Aires, Argentina.

Carballo J. L., Hernández-Inda Z. L., Pérez P., and García Grávalos M. D. (2002), A comparison between two brine shrimp assays to detect in vitro cytotoxicity in marine natural products. BMC Biotechnol. 2, 17-21.

Dikshit A., Naqvi A. A., and Husain A. (1986), Schinus molle: a new source of natural fungitoxicant. Appl. Environ. Microbiol. 51, 1085-1088.

Gundidza M. (1993), Antimicrobial activity of essential oil from Schinus molle Linn. Cent. Afr. J. Med. 39, 231-234.

Gupta M. P. (1995), 270 Plantas Medicinales Iberoamericanas. Ed. CYTED-SECAB, Bogotá, Colombia, pp. $21-24$.

Mackeen M. M., Ali A. M., Lajis N. H., Kawazu K., Hassan Z., Amran M., Habsah M., Mooi L. Y., and Mohamed S. M. (2000), Antimicrobial, antioxidant, antitumour-promoting and cytotoxic activities of different plant part extracts of Garcinia atroviridis Griff. ex T. Anders. J. Ethnopharm. 72, 395-402.

McLaughlin J. L., Chang C. J., and Smith D. L. (1991), "Bench top" bioassay for the discovery of bioactive natural products: an update. In: Studies in Natural Products Chemistry, vol. 9 (Rahman A. U., ed.). Elsevier, Amsterdam, The Netherlands, pp. 383-409.

Meyer B. N., Ferrigni N. R., Putnam J. E., Jacobsen L. B., Nichols D. E., and McLaughlin J. L. (1982), Brine shrimp: A convenient general bioassay for active plant constituents. Planta Med. 45, 31-34.
Scarpa G. F. (2004), Medicinal plants used by the Criollos of Northwestern Argentine Chaco. J. Ethnopharm. 91, 115-135.

Scrivanti L. R., Zunino M. P., and Zygadlo J. A. (2003), Tagetes minuta and Schinus areira essential oils as allelopathic agents. Biochem. Syst. Ecol. 31, 563572.

Solis P. N., Wright C. W., Anderson M. M., Gupta M. P., and Phillipson J. D. (1993), A microwell cytotoxicity assay using Artemia salina. Planta Med. 59, $250-252$.

Sorgeloos P., Remiche-Van Der Wielen C., and Persoone G. (1978), The use of Artemia nauplii fro toxicity tests. A critical analysis. Ecotoxicol. Env. Saf. 2, 249-255.

Viturro C. I., Molina A. C., and Campos E. (2003), Variación de metabolitos volátiles en Schinus areira L. Presented at XIV th National Symposium of Organic Chemistry, Rosario, Argentina.

Wannaz E. D., Zygadlo J. A., and Pignata M. L. (2003), Air pollutants effect on monoterpenes composition and foliar chemical parameters in Schinus areira L. Sci. Total Environ. 305, 177-193.

Zuloaga F. O. and Morrone O. (1999), Catálogo de Plantas Vasculares de la República Argentina II. In: Monographs in Systematic Botany from the Missouri Botanical Garden, vol. 74. Ed. Missouri Botanical Garden Press, St. Louis, MO, USA, pp. 43-44. 